\title{
Neotropical Insect Galls
}

Geraldo Wilson Fernandes Jean Carlos Santos (Editores)

Resenha feita por G.L.G. Soares Laboratório de Ecologia Química e Quimiotaxonomia -

Departamento de Botânica Universidade Federal do Rio Grande do Sul

Há aproximadamente 30 anos, pesquisadores brasileiros de diversas áreas do conhecimento biológico despertaram a atenção para um grupo particular de insetos herbívoros. Esses insetos, os galhadores, são sésseis e, devido ao íntimo contato com as células vegetais, provocam alteraçóes complexas na estrutura e na fisiologia de suas plantas hospedeiras. Esse modelo particular de interaçáo insetoplanta estimulou primeiramente pesquisas concentradas nas regióes temperadas do hemisfério norte e tocavam diversos ângulos do conhecimento destas interaçôes de grande complexidade. Pouco a pouco, nos neotrópicos, os estudos de galhas foram reforçandoo conceito destas estruturas como o fenótipo estendido dos galhadores. Surge entấo a necessidade de buscar terminologias mais precisas para descrever a diversidade de formas das galhas e as interaçóes encontradas entre os insetos galhadores e suas hospedeiras. Foi natural surgir o interesse também pelos aspectos particulares da Ecologia e da Fisiologia das galhas.

O desenvolvimento dessas pesquisas, somado a riqueza dos modelos de galhas encontrados no Brasil, contribuiu para a formação de núcleos de excelência que agregam pesquisadores das mais diversas áreas do conhecimento biológico - desde a Entomologia à Botânica, passando pela Ecologia de Populaçóes e Comunidades, Fisiologia vegetal e pela Ecologia Química. Esse despertar progressivo culminou com a edição do "Workshop - Geographyofgall-inducinginsects in South and Meso-America" realizado na cidade de Recife em Setembro de 
2007, no qual pesquisadores de diversas regióes do Brasil, latinoamericanos e norte-americanos se reuniram para compartilhar suas experiências, ficando claro a partir daí que o Brasil se constituía num centro de estudos de galhas neotropicais.

O livro Neotropical InsectGalls é resultado da experiência adquirida pelos pesquisadores brasileiros dedicados ao estudo da Cecidologia - possivelmente um dos braços mais interdisciplinares das Ciências Biológicas. Esse livro, ao mesmo tempo em que preenche uma lacuna na literatura especializada sobre o assunto, inspira novas pesquisas por trazer o estado da arte e os avanços realizados por pesquisadores das mais distintas áreas focando na grande diversidade de galhas, tanto no que diz respeito aos modelos indutor-planta hospedeira, quanto aos ecossistemas onde elas ocorrem.

Seguindo uma excelente revisão do estado da arte do conhecimento de galhas neotropicais temos capítulos que versam sobre anatomia, fisiologia e ecologia de galhas. Há também capítulos contemplando inventários de galhas em diversas regiôes do Brasil, além de Argentina, Chile, Costa Rica e México. Nessa obra pode-se encontrar a primeira tentativa - leia-se bem sucedida - de sistematização dos morfotipos de galhas.

Enfim, assim como um dos mais intrigantes modelos de interação entre inseto e planta tem na formação da galha a sua manifestação transcendental - representada pela extensão da forma do indutor somada a todas as reaçóes da hospedeira - o presente livro ultrapassa os limites do conhecimento biológico tradicional, reúne conhecimentos de diversas áreas, e compreende o estado da arte da Cecidologia Neotropical apresentando com excelência o enfoque multidisciplinar tão almejado em diversas áreas da Ciência. Essa qualidade faz do livro Neotropical InsectGalls obra de inestimável valor e de leitura obrigatória para profissionais e estudantes das áreas de Ecologia, Entomologia e Botânica. 


\section{REFERÊNCIA BILIOGRÁFICA}

Fernandes, Geraldo Wilson \& SANTOS, Jean Carlos. 2014.

Neotropical Insect Galls. Dordrecht: Spinger. 550p. 